\title{
Development of Mangalarga Marchador suckling foals supplemented with fructooligosaccharides
}

\author{
Ana Carla Chaves Dias ${ }^{1}$, Grasiele Coelho Cabral', Camila Ferreira e Silva ${ }^{1}$, Marcelle Christine \\ Nascimento Ferreira ${ }^{2}$, Tatiana Werneck $\mathrm{Franco}^{3}$, Raiane Araújo Moura², Vinícius Pimentel \\ Silva ${ }^{3}$, Fernando Queiroz de Almeida ${ }^{2^{*}}$
}

\footnotetext{
1 Universidade Federal Rural do Rio de Janeiro, Programa de Pós-graduação em Zootecnia, Seropédica, RJ, Brazil.

${ }^{2}$ Universidade Federal Rural do Rio de Janeiro, Instituto de Veterinária, Seropédica, RJ, Brazil.

${ }^{3}$ Universidade Federal Rural do Rio de Janeiro, Instituto de Zootecnia, Seropédica, RJ, Brazil.
}

ABSTRACT - The objective of this study was to evaluate the effect of prebiotic fructooligosaccharide (FOS) supplementation on the development of Mangalarga Marchador suckling foals. Sixteen Mangalarga Marchador foals, from birth to 75 days of age, were evaluated in a completely randomized design, with two treatments (experimental group and control group) with eight repetitions (animals). The foals were evaluated through body weight, morphometric, and circumferential measures. The daily, weekly, and cumulative weight gains were recorded and the morphometric measures were: withers height, croup height, body length, mid-back height, mid-back width, and thorax, shin, knee, and forearm circumferences. The mean body weight was 32.3 and $77.9 \mathrm{~kg}$ at birth and 75 days of age, respectively. The mean withers height was 86 and $103.8 \mathrm{~cm}$ at birth and 75 days of age, respectively, and the mean body length was $63.9 \mathrm{~cm}$ at birth, reaching $89.1 \mathrm{~cm}$ at 75 days of age. No significant differences in the FOS supplementation or interaction of age versus supplementation between the experimental and control groups were observed for any of the parameters evaluated. However, there were significant differences between the ages. Supplementation with prebiotic FOS does not affect the development of the Mangalarga Marchador suckling foals from birth to 75 days of age.

Key Words: body weight, equines, inulin, morphometric measures, performance, prebiotic

\section{Introduction}

Fructooligosaccharides (FOS) are prebiotic additives composed of medium and short-chain fructose molecules linked by a $\beta$ 2-1 glycosidic bond (Gibson and Wang, 1994). The digestive enzymes present in the mammals cannot hydrolyze these bonds and, therefore, FOS become a substrate for the microorganisms present in the digestive tract, stimulating the production of beneficial bacteria that can hydrolyze these bonds. Fructooligosaccharides act as a source of energy for bacteria, which in turn releases lactic acid and volatile fatty acids as fermentation products and these acids lower the intestinal $\mathrm{pH}$ and inhibit the growth of pathogenic bacteria (Gibson and Roberfroid, 1995).

Received: March 30, 2017

Accepted: July 5, 2017

*Corresponding author: almeidafq@yahoo.com.br

http://dx.doi.org/10.1590/S1806-92902017000900006

How to cite: Dias, A. C. C.; Cabral, G. C.; Silva, C. F.; Ferreira, M. C. N.; Franco, T. W.; Moura, R. A.; Silva, V. P. and Almeida, F. Q. 2017. Development of Mangalarga Marchador suckling foals supplemented with fructooligosaccharides. Revista Brasileira de Zootecnia 46(9):747-754.

Copyright (C) 2017 Sociedade Brasileira de Zootecnia. This is an Open Access article distributed under the terms of the Creative Commons Attribution License (http://creativecommons.org/licenses/by/4.0/), which permits unrestricted use, distribution, and reproduction in any medium, provided the original work is properly cited.
Knowledge about the effects of prebiotics on foal nutrition and development is limited, but prebiotics have been shown to have a positive influence on the bacterial colonization of the digestive tract and, consequently, improve nutrient digestibility. In addition, they improve the gastrointestinal well-being by reducing disorders such as colic and diarrhea, which are significant causes of mortality for growing foals (Magdesian, 2005). Positive effects of prebiotics has been reported for other species. Van Leeuwen and Verdonk (2004) demonstrated improved growth and feed conversion in calves with prebiotics added to milk substitutes. In addition, in broilers challenged with salmonella, the FOS supplementation suppressed infections and a marked positive impact was observed on their development indices (Waldroup et al., 1993).

There are no studies with prebiotic supplementation in growing foals, with effects on the animal performance. The influence on the bacterial ecosystem in foals could, in the future, affect the intestinal bacterial composition in adult horses, as already observed in other species (Thompson et al., 2008; Yáñez-Ruiz et al., 2010) and, therefore, influence digestive efficiency. Thus, nutritional strategies such as the inclusion of fructooligosaccharides during the neonatal period could influence the growth of horses; therefore, the objective of this study was to 
evaluate the effects of prebiotic FOS supplementation on the development of suckling foals from birth to 75 days of age.

\section{Material and Methods}

The present experiment was carried out on a farm located in Rio Claro, Rio de Janeiro, Brazil (22 $51^{\circ} 06.9^{\prime \prime S}$ latitude, 435 $57^{\prime} 29.6^{\prime \prime} \mathrm{W}$ longitude, and $526 \mathrm{~m}$ altitude). The research was conducted according to the institutional Ethics Committee on Animal Use under case no.: 004403/ 2015-45.

Sixteen Mangalarga Marchador foals, from birth to 75 days of age, were used in a completely randomized design, with two treatments. There were eight repetitions (animals) in each group. The foals of experimental group were supplemented with prebiotic FOS and the foals of control group did not receive any supplementation. The sex of the animals was randomly distributed and the supplemented and control groups were composed of 62.5 and $50 \%$ of female foals, respectively.

The prebiotic FOS used was chicory inulin $\left(\mathrm{Orafti}^{\circledR}\right.$ SIPX, Beneo Institute - Connecting Nutrition and Health, Germany). The experimental group of foals received the FOS supplemented at a dose of $0.07 \mathrm{~g} / \mathrm{kg}$ body weight orally, using $20-\mathrm{mL}$ syringes after diluting the FOS in distilled water each morning. Dosages were adjusted weekly per foal according to their body weight. The foals of the control group received only distilled water in the same volume and in the same way.

The foals were kept with their mothers in paddocks fitted with feeders. The mares were fed commercial concentrate and corn silage with a $35 \%$ dry matter content, in two meals per day. The animals had ad libitum access to water and mineral salt and were subjected to ectoparasite and endoparasite control using ivermectin and doramectin, respectively. The foals were subjected to rational dressage to facilitate handling, weighing, and measurements.

The evaluation of their development was based on body weight and morphometric measures. All measurements were performed mostly by the same person to avoid large variations. The foals were weighed at birth and weekly up until they were 75 days of age using an electro-mechanical platform scale (Balmak ${ }^{\circledR}$, BKH-1000) to calculate the daily, weekly, and cumulative weight gain. A hipometer recorded the following morphometric measures: withers height, croup height, body length, mid-back height, and mid-back width. The withers height was the distance from the ground to the highest point of the interscapular region, located in the space defined by the spinous processes of the 5 th and 6th thoracic vertebrae; croup height was the distance from the ground to the highest croup point, the sacral tuberosity; the body length was the distance between the cranial part of the major humerus tubercle and the ischial tuberosity; the mid-back height was the distance from the highest point of withers to the sternum; and the mid-back width was the distance from the caudal end of the withers, comprising the space between the right and left border of the two side regions (Cabral et al., 2004, Pinto et al., 2008; Godoi et al., 2013). The substernal height was defined as the distance from the ground to the base of sternum and was calculated in this study by subtracting the withers height.

The circumferential measures were made with a tape measure for the thorax, shin, knee, and forearm circumferences. The thoracic circumference measure passes through the caudal end of the withers, between the spinous processes $\mathrm{T} 8$ and $\mathrm{T} 9$, until the articulation of the last rib with the xiphoid process. The shin circumference is measured in the middle region of the shin of one of the anterior limbs, formed by the metacarpal bones II, III, and IV. The knee circumference is the measure around the median region of the knee, including the carpal bones. The forearm circumference was measured around the medial region formed by the radius and ulna bones (Cabral et al., 2004, Pinto et al., 2008; Godoi et al., 2013).

These values were subjected to analysis of variance in split-splot design and the treatments were evaluated in the plots and time (age) in the subplots. The mean values were compared by the Student Newman Keuls test $(\mathrm{P}<0.05)$. If the effects of age were significant, the results were subjected to regression analysis. The analyses were carried out using the SAEG software (System of Statistical and Genetic Analysis, version 8.0). Suckling foals did not receive different nutritional treatment in the experimental period, so males and females were not separated for the statistical analysis.

\section{Results}

The prebiotic FOS supplementation did not have any effect on the development of the foals $(\mathrm{P}>0.05)$. However, there was the effect of age $(\mathrm{P}<0.05)$ for all development variables. The mean body weight at birth in this work was $32.3 \mathrm{~kg}$ and reached $77.9 \mathrm{~kg}$ at 75 days of age (Figure 1), corresponding to 8.2 and $19.7 \%$ of the maternal body weight, respectively.

Mean daily weight gain was 1.0 and $0.5 \mathrm{~kg}$ in the first week and last week, respectively (Table 1). The mean daily weight gain was $0.63 \mathrm{~kg}$ for the total experimental period. The weekly weight gain (WWG) ranged from $7.0 \mathrm{~kg}$ 
in the first week to $2.2 \mathrm{~kg}$ at the end of the survey, in the 11 th week (Table 1), which corresponds to a decrease of $68.6 \%$. The highest WWG was observed during the first three weeks $(\mathrm{P}<0.05)$, with a mean of $6.5 \mathrm{~kg}$. The cumulative weight gain increased from $7.0 \mathrm{~kg}$ in the first week to $45.5 \mathrm{~kg}$ at 75 days of age, corresponding to a gain of $84.6 \%$ (Table 1).

There was no effect of the prebiotic FOS supplement or the interaction of age versus supplementation $(\mathrm{P}>0.05)$ on withers height, croup height, mid-back height, and width, substernal height, body length, and thoracic, forearm, knee, and shin circumferences. However, there was an effect of age $(\mathrm{P}<0.05)$ for all the variables (Table 2$)$.

Table 1 - Mean values and standard deviation of weight gain in foals supplemented and not supplemented with fructooligosaccharides over eleven weeks

\begin{tabular}{lccc}
\hline $\begin{array}{l}\text { Age } \\
\text { (weeks) }\end{array}$ & $\begin{array}{c}\text { Daily weight gain } \\
(\mathrm{DWG})\end{array}$ & $\begin{array}{c}\text { Weekly weight gain } \\
\text { (WWG) }\end{array}$ & $\begin{array}{c}\text { Cumulative } \\
\text { weight gain }(\mathrm{CWG})\end{array}$ \\
\hline 1 & $1.0 \pm 0.2 \mathrm{a}$ & $7.0 \pm 1.4 \mathrm{a}$ & $7.0 \pm 1.4 \mathrm{j}$ \\
2 & $0.90 \pm 0.2 \mathrm{a}$ & $6.3 \pm 1.1 \mathrm{a}$ & $13.3 \pm 1.6 \mathrm{i}$ \\
3 & $0.89 \pm 0.2 \mathrm{a}$ & $6.2 \pm 1.2 \mathrm{a}$ & $19.5 \pm 2.1 \mathrm{~h}$ \\
4 & $0.70 \pm 0.6 \mathrm{~b}$ & $4.9 \pm 1.1 \mathrm{~b}$ & $24.1 \pm 2.9 \mathrm{~g}$ \\
5 & $0.61 \pm 0.1 \mathrm{bc}$ & $4.3 \pm 1.0 \mathrm{bc}$ & $28.3 \pm 3.2 \mathrm{f}$ \\
6 & $0.61 \pm 0.6 \mathrm{bc}$ & $4.3 \pm 1.1 \mathrm{bc}$ & $32.6 \pm 4.0 \mathrm{e}$ \\
7 & $0.55 \pm 0.2 \mathrm{bc}$ & $3.9 \pm 1.2 \mathrm{~cd}$ & $36.5 \pm 4.4 \mathrm{~d}$ \\
8 & $0.51 \pm 0.2 \mathrm{c}$ & $3.6 \pm 1.1 \mathrm{~cd}$ & $40.1 \pm 4.8 \mathrm{c}$ \\
9 & $0.48 \pm 0.2 \mathrm{c}$ & $3.0 \pm 1.3 \mathrm{~d}$ & $41.4 \pm 7.4 \mathrm{bc}$ \\
10 & $0.51 \pm 0.2 \mathrm{c}$ & $3.3 \pm 1.3 \mathrm{~cd}$ & $43.9 \pm 8.4 \mathrm{ab}$ \\
11 & $0.50 \pm 0.3 \mathrm{c}$ & $2.2 \pm 1.5 \mathrm{e}$ & $45.5 \pm 9.6 \mathrm{a}$ \\
\hline
\end{tabular}

Means followed by different letters in the columns differ according to the SNK test $(\mathrm{P}<0.05)$.

Effects: supplementation $=$ not significant $(\mathrm{NS})$; age: 0.000 ; supplementation $\times$ age $=$ $\mathrm{NS}$; coefficient of variation $(\mathrm{CV})(\mathrm{DWG})=26.1 \%$; CV $(\mathrm{WWG})=25.5 \%$; $\mathrm{CV}(\mathrm{CWG})=$ $13.0 \%$

Linear regression $(\mathrm{DWG}): \hat{\mathrm{Y}}=0.972-0.051 \mathrm{X}\left(\mathrm{r}^{2}=41 \%\right)$; linear regression $(\mathrm{WWG}): \hat{\mathrm{Y}}=7.101-0.44 \mathrm{X}\left(\mathrm{r}^{2}=55.1 \%\right)$; linear regression $(\mathrm{CWG}): \hat{\mathrm{Y}}=7.253+$ $3.828 \mathrm{X}\left(\mathrm{r}^{2}=82 \%\right)$, in which, in all models, $\hat{\mathrm{Y}}$ is the weight and $\mathrm{X}$ is the age of the animal in days.
The mean of withers height at birth was $86 \mathrm{~cm}$, reaching $103.8 \mathrm{~cm}$ at 75 days of age. The withers height increased $17.8 \mathrm{~cm}$ during the evaluated period. The withers height at birth and at 75 days of age corresponded to 59.6 and $71.7 \%$ of the mare withers height, respectively. The mean croup height at birth was $87.9 \mathrm{~cm}$, reaching $106.6 \mathrm{~cm}$ at 75 days of age. The average mid-back height and width were 28.3 and $16.9 \mathrm{~cm}$ at birth, reaching 37.1 and $26 \mathrm{~cm}$ at 75 days of age, respectively. This corresponds to a growth of 31.1 and $53.8 \%$ of midback height and width, respectively, in the same period. The substernal height at birth was $57.7 \mathrm{~cm}$, reaching $66.7 \mathrm{~cm}$ at the end of the research period, when the foals were 75 days of age, characterizing a $15.6 \%$ growth in this period.

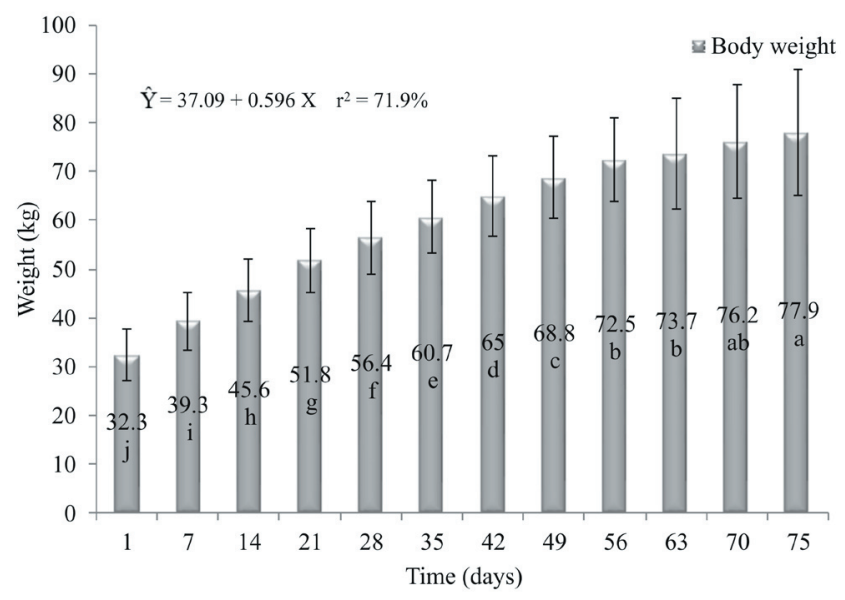

Means followed by different letters differ according to the SNK test $(\mathrm{P}<0.05)$. Effects: supplementation $=$ not significant $(\mathrm{NS}) ;$ age $=0.000 ;$ supplementation $\times$ age $=$ NS; coefficient of variation $=1.4 \%$.

Figure 1 - Mean values and standard deviations of body weight $(\mathrm{kg})$ of foals supplemented and not supplemented with fructooligosaccharides from birth to 75 days of age.

Table 2 - Means and standard deviations of height and width measures of foals supplemented and not supplemented with fructooligosaccharides from birth to 75 days of age

\begin{tabular}{|c|c|c|c|c|c|}
\hline Age (days) & Withers height (WH; cm) & Croup height $(\mathrm{CH} ; \mathrm{cm})$ & Mid back height $(\mathrm{MH} ; \mathrm{cm})$ & Mid back width (MW; cm) & Substernal height $(\mathrm{SH} ; \mathrm{cm})$ \\
\hline 1 & $86.0 \pm 5.2 \mathrm{k}$ & $87.8 \pm 4.9 \mathrm{~h}$ & $28.3 \pm 1.6 \mathrm{j}$ & $16.9 \pm 1.7 \mathrm{i}$ & $57.7 \pm 3.3 f$ \\
\hline 7 & $89.0 \pm 3.9 \mathrm{j}$ & $91.3 \pm 3.8 \mathrm{~g}$ & $29.6 \pm 1.5 \mathrm{i}$ & $18.7 \pm 1.6 \mathrm{~h}$ & $59.7 \pm 2.6 \mathrm{e}$ \\
\hline 14 & $91.5 \pm 3.2 \mathrm{i}$ & $93.8 \pm 3.7 f$ & $31.4 \pm 1.5 \mathrm{~h}$ & $20.1 \pm 1.1 \mathrm{~g}$ & $60.2 \pm 2.3 \mathrm{e}$ \\
\hline 21 & $94.2 \pm 3.4 \mathrm{~h}$ & $96.9 \pm 4.5 \mathrm{e}$ & $32.6 \pm 1.1 \mathrm{~g}$ & $20.5 \pm 1.6 \mathrm{~g}$ & $61.7 \pm 2.7 \mathrm{~d}$ \\
\hline 28 & $95.9 \pm 3.5 \mathrm{~g}$ & $98.7 \pm 4.5 \mathrm{~d}$ & $33.3 \pm 1.4 \mathrm{f}$ & $21.4 \pm 1.6 \mathrm{f}$ & $62.5 \pm 2.8 \mathrm{~cd}$ \\
\hline 35 & $97.9 \pm 4.0 f$ & $100.8 \pm 4.5 \mathrm{c}$ & $34.5 \pm 1.4 \mathrm{e}$ & $22.4 \pm 1.5 \mathrm{e}$ & $63.4 \pm 3.2 \mathrm{c}$ \\
\hline 42 & $99.8 \pm 3.5 \mathrm{e}$ & $102.7 \pm 4.5 b$ & $34.9 \pm 1.4 \mathrm{de}$ & $23.4 \pm 1.1 \mathrm{~d}$ & $64.9 \pm 2.7 b$ \\
\hline 49 & $100.7 \pm 3.5 \mathrm{de}$ & $103.9 \pm 4.5 b$ & $35.6 \pm 1.3 \mathrm{~cd}$ & $24.3 \pm 1.4 \mathrm{c}$ & $65.2 \pm 2.6 \mathrm{ab}$ \\
\hline 56 & $101.7 \pm 3.7 \mathrm{~cd}$ & $105.5 \pm 4.1 \mathrm{a}$ & $36.1 \pm 1.3 \mathrm{bc}$ & $24.7 \pm 1.3 \mathrm{bc}$ & $65.7 \pm 2.9 \mathrm{ab}$ \\
\hline 63 & $102.3 \pm 4.0 \mathrm{bc}$ & $105.9 \pm 4.5 \mathrm{a}$ & $36.5 \pm 1.9 \mathrm{ab}$ & $25.3 \pm 1.7 \mathrm{abc}$ & $66.0 \pm 2.3 \mathrm{ab}$ \\
\hline 70 & $103.5 \pm 4.1 \mathrm{ab}$ & $106.4 \pm 4.6 \mathrm{a}$ & $36.9 \pm 2.0 \mathrm{ab}$ & $25.8 \pm 1.7 \mathrm{ab}$ & $66.0 \pm 2.0 \mathrm{ab}$ \\
\hline 75 & $103.8 \pm 3.8 \mathrm{a}$ & $106.6 \pm 5.5 \mathrm{a}$ & $37.1 \pm 2.4 \mathrm{a}$ & $26.0 \pm 1.8 \mathrm{a}$ & $66.7 \pm 2.1 \mathrm{a}$ \\
\hline
\end{tabular}

Means followed by different letters in the columns differ according to the SNK test $(\mathrm{P}<0.05)$.

Effects: supplementation $=$ not significant $(\mathrm{NS})$; age $=0.000 ;$ supplementation $\times$ age $=\mathrm{NS} ;$ coefficient of variation $(\mathrm{CV})(\mathrm{WH})=1.7 \% ; \mathrm{CV}(\mathrm{CH})=2.0 \% ; \mathrm{CV}(\mathrm{MH})=4.8 \%$; $\mathrm{CV}(\mathrm{MW})=2.8 \% ; \mathrm{CV}(\mathrm{SH})=2.7 \%$. 
The mean body length at birth was $63.9 \mathrm{~cm}$, reaching $89.1 \mathrm{~cm}$ at 75 days of age (Table 3 ). Therefore, there was an increase of $39.4 \%$ from birth to 75 days of age, corresponding to $25.2 \mathrm{~cm}$. The mean value of body length at birth and at 75 days of age corresponds to 42.2 and $58.9 \%$ of the body length of mares, respectively. In this study, the body length of foals at birth and at 75 days of age corresponded to 42.2 and $58.9 \%$ of the maternal body length, respectively. The mean thoracic circumference of foals at birth was $70.9 \mathrm{~cm}$, reaching $98.4 \mathrm{~cm}$ at 75 days of age (Table 3 ). The thoracic circumference at birth and at 75 days of age, in this study, corresponds to 41.4 and $57.5 \%$, respectively, of the thoracic circumference of mares.

The mean forearm circumference at birth was $20.5 \mathrm{~cm}$, reaching $25.1 \mathrm{~cm}$ at 75 days of age (Table 3), corresponding to an average growth of $22.4 \%$. The mean knee circumference of foals at birth was $20.0 \mathrm{~cm}$, reaching $22.4 \mathrm{~cm}$ at 75 days of age (Table 3 ). The mean growth of the knee circumference was $12 \%$, from birth to 75 days of age. The mean shin circumference at birth was $12.2 \mathrm{~cm}$, reaching $13.7 \mathrm{~cm}$ at the end of this study, when foals were
75 days of age (Table 3). Shin circumference presented the smallest variation in this study. There was an average increase of $12.3 \%$ from birth to 75 days of age.

The linear regression models were adjusted for the height, width, length, and circumference variables of the Mangalarga Marchador suckling foals supplemented or not with FOS (Table 4). The foals evaluated in the present experiment present growth characteristics under a tropical climate inherent to this region of the country. Although these equations can be used under different climates, more information on the morphometric measures are necessary to better understand the development of horses in the first three months of age.

\section{Discussion}

Research evaluating foal supplementation with prebiotics is still very limited. Faubladier et al. (2013), evaluating foals of mares supplemented with prebiotics (lactic fermentation products and sprouted cereal seed), observed larger weight of these foals compared with

Table 3 - Means and standard deviations of measures of body length and circumferences for foals supplemented or not with fructooligosaccharides, from birth to 75 days of age

\begin{tabular}{|c|c|c|c|c|c|}
\hline Age (days) & $\begin{array}{l}\text { Body length } \\
(\mathrm{BL} ; \mathrm{cm})\end{array}$ & $\begin{array}{l}\text { Thoracic circumference } \\
(\mathrm{TC} ; \mathrm{cm})\end{array}$ & $\begin{array}{l}\text { Forearm circumference } \\
\qquad(\mathrm{FC} ; \mathrm{cm})\end{array}$ & $\begin{array}{l}\text { Knee circumference } \\
(\mathrm{KC} ; \mathrm{cm})\end{array}$ & $\begin{array}{c}\text { Shin circumference } \\
(\mathrm{SC} ; \mathrm{cm})\end{array}$ \\
\hline 1 & $63.9 \pm 3.5 \mathrm{k}$ & $70.9 \pm 3.6 \mathrm{k}$ & $20.5 \pm 1.3 \mathrm{~h}$ & $20.0 \pm 0.9 \mathrm{~h}$ & $12.2 \pm 0.8 \mathrm{e}$ \\
\hline 7 & $68.4 \pm 4.2 \mathrm{j}$ & $76.4 \pm 3.8 \mathrm{j}$ & $21.0 \pm 1.5 \mathrm{~g}$ & $20.2 \pm 0.8 \mathrm{~g}$ & $12.2 \pm 0.7 \mathrm{e}$ \\
\hline 14 & $72.6 \pm 3.6 \mathrm{i}$ & $80.3 \pm 3.3 \mathrm{i}$ & $21.4 \pm 1.7 \mathrm{~g}$ & $20.4 \pm 1.0 \mathrm{f}$ & $12.2 \pm 0.7 \mathrm{e}$ \\
\hline 21 & $75.7 \pm 3.4 \mathrm{~h}$ & $83.7 \pm 3.0 \mathrm{~h}$ & $22.3 \pm 1.3 f$ & $20.9 \pm 0.9 \mathrm{e}$ & $12.3 \pm 0.6 \mathrm{e}$ \\
\hline 28 & $77.9 \pm 4.1 \mathrm{~g}$ & $85.9 \pm 2.9 \mathrm{~g}$ & $22.7 \pm 1.4 \mathrm{ef}$ & $21.4 \pm 0.9 \mathrm{dh}$ & $12.6 \pm 0.6 \mathrm{~d}$ \\
\hline 35 & $79.9 \pm 4.1 \mathrm{f}$ & $88.6 \pm 3.9 f$ & $23.0 \pm 1.1 \mathrm{de}$ & $21.7 \pm 0.6 \mathrm{cefg}$ & $12.8 \pm 0.7 \mathrm{~cd}$ \\
\hline 42 & $82.0 \pm 4.0 \mathrm{e}$ & $90.9 \pm 3.4 \mathrm{e}$ & $23.5 \pm 1.4 \mathrm{~cd}$ & $21.8 \pm 0.6 \mathrm{bef}$ & $13.0 \pm 0.7 \mathrm{c}$ \\
\hline 49 & $84.4 \pm 3.7 \mathrm{~d}$ & $93.4 \pm 3.6 \mathrm{~d}$ & $23.7 \pm 1.4 b c$ & $21.9 \pm 0.7$ acde & $13.3 \pm 0.5 b$ \\
\hline 56 & $86.1 \pm 3.8 \mathrm{c}$ & $95.0 \pm 3.4 \mathrm{c}$ & $24.0 \pm 1.4 b c$ & $22.2 \pm 1.0 \mathrm{abcd}$ & $13.4 \pm 0.5 \mathrm{ab}$ \\
\hline 63 & $86.9 \pm 5.6 b c$ & $96.0 \pm 5.4 \mathrm{bc}$ & $24.4 \pm 1.2 \mathrm{ab}$ & $22.2 \pm 1.1 \mathrm{abc}$ & $13.5 \pm 0.7 \mathrm{ab}$ \\
\hline 70 & $88.3 \pm 5.6 \mathrm{ab}$ & $97.4 \pm 4.8 \mathrm{ab}$ & $25.0 \pm 1.3 \mathrm{a}$ & $22.3 \pm 1.0 \mathrm{ab}$ & $13.7 \pm 0.7 \mathrm{a}$ \\
\hline 75 & $89.1 \pm 5.7 \mathrm{a}$ & $98.4 \pm 5.6 \mathrm{a}$ & $25.1 \pm 1.5 \mathrm{a}$ & $22.4 \pm 1.0 \mathrm{a}$ & $13.7 \pm 0.7 \mathrm{a}$ \\
\hline
\end{tabular}

Means followed by different letters in the columns differ according to the SNK test $(\mathrm{P}<0.05)$

Effects: supplementation $=$ not significant $(\mathrm{NS})$; age $=0.000 ;$ supplementation $\times$ age $=\mathrm{NS} ;$ coefficient of variation $(\mathrm{CV})(\mathrm{BL})=2.5 \% ; \mathrm{CV}(\mathrm{TC})=2.4 \% ; \mathrm{CV}(\mathrm{FC})=1.1 \% ; \mathrm{CV}(\mathrm{KC})=$ $2.0 \% ; \mathrm{CV}(\mathrm{SC})=1.1 \%$.

Table 4 - Regression equations for the withers height, croup height, mid-back height and width, substernal height, body length, and thorax, forearm, knee, and shin circumferences of foals supplemented or not with fructooligosaccharides from birth to 75 days of age

\begin{tabular}{|c|c|c|c|}
\hline Morphometric measure & Equation & $\mathrm{r}^{2}$ & P-value \\
\hline Withers height & $\hat{\mathrm{Y}}=88.31+0.231 \mathrm{X}$ & 0.814 & $<0.0001$ \\
\hline Croup height & $\hat{\mathrm{Y}}=90.52+0.247 \mathrm{X}$ & 0.787 & $<0.0001$ \\
\hline Mid-back height & $\hat{Y}=29.53+0.113 X$ & 0.839 & $<0.0001$ \\
\hline Mid-back width & $\hat{\mathrm{Y}}=17.96+0.117 \mathrm{X}$ & 0.872 & $<0.0001$ \\
\hline Substernal height & $\hat{\mathrm{Y}}=58.91+0.114 \mathrm{X}$ & 0.711 & $<0.0001$ \\
\hline Body length & $\hat{\mathrm{Y}}=67.3+0.32 \mathrm{X}$ & 0.857 & $<0.0001$ \\
\hline Thoracic circumference & $\hat{\mathrm{Y}}=74.77+0.346 \mathrm{X}$ & 0.888 & $<0.0001$ \\
\hline Forearm circumference & $\hat{\mathrm{Y}}=20.75+0.060 \mathrm{X}$ & 0.726 & $<0.0001$ \\
\hline Knee circumference & $\hat{\mathrm{Y}}=20.19+0.033 \mathrm{X}$ & 0.679 & $<0.0001$ \\
\hline Shin circumference & $\hat{\mathrm{Y}}=12.01+0.024 \mathrm{X}$ & 0.669 & $<0.0001$ \\
\hline
\end{tabular}

In the linear regression equation, $\hat{\mathrm{Y}}$ is the morphometric measure variable and $\mathrm{X}$ is the age of the animal in days. 
foals of control group at 19, 26, 40, 54, and 60 days old. However, in the present study, direct supplementation of the prebiotic FOS did not improve the growth rates of the variables evaluated in the foals.

Some studies with prebiotic supplementation in mature horses have shown similar results to those observed in the present work. Gürbüz et al. (2010) evaluated mature horses receiving supplementation of FOS (30 g/day), mannan oligosaccharides (MOS; 30g/day), and FOS + MOS (15 g/day/each) and did not observe any changes in the weight of the animals, probably because when assessed, they had reached the respective adult weight and did not present any stress situation. The same occurred in the study of Respondek et al. (2011), who evaluated obese mature horses after supplementation of FOS for six weeks (45 g/day), and did not observe any significant alteration in weight of the experimental and control horses.

The mean body weight of foals at birth, $32.3 \mathrm{~kg}$, and $8.2 \%$ of the maternal weight was similar to that observed in a study by Almeida et al. (2000) with Mangalarga Marchador foals, who observed mean values of body weight at birth of $34.6 \mathrm{~kg}$, equivalent to $8 \%$ of the body weight of adults. In foals of the same breed, Cabral et al. (2004) reported a birth weight equivalent to 9.7 and $11 \%$ of the maternal weight for male and female foals, respectively, while Santos et al. (2005) observed $39.4 \mathrm{~kg}$ for foals at birth, equivalent to $9.3 \%$ of the body weight of mature horses.

The weight of foals at 42 days old in this work more than doubled, ranging from $32.3 \mathrm{~kg}$ at birth to $65.0 \mathrm{~kg}$ at 42 days old, representing an increase of $101.2 \%$. Santos et al. (2005) observed similar results, with foals of $39.4 \mathrm{~kg}$ and $72.4 \mathrm{~kg}$, from birth to 40 days old, respectively, representing $83.7 \%$ gain in body weight. In other words, regardless of supplementation, foals reached a percentage of body weight gain at the end of the study compatible with that expected for the breed at that same age.

During the first three weeks, there was a greater daily weight gain, reaching a daily average value of $0.93 \mathrm{~kg}$, close to that observed by Santos et al. (2005) $(0.95 \mathrm{~kg} /$ day) during the first 20 days of life. The result observed for weekly weight gain $(6.5 \mathrm{~kg})$ was close to estimative of the NRC (2007), which corresponds to $6.3 \mathrm{~kg}$ in the first month of foals with adults weighing $400 \mathrm{~kg}$. The cumulative weight gain was similar to that observed by Santos et al. (2005), considering the body weight at 75 days of age $(45.5 \mathrm{~kg})$. Santos et al. (2005) recorded an average cumulative value of $47.8 \mathrm{~kg}$ at 80 days old, which is a variation of $2.3 \mathrm{~kg}$ for foals of the same breed. As reported above, the weight gain was in agreement with the literature data, our experimental model appeared suitable for studying the growing of Mangalarga Marchador suckling foals.

There was a lower dispersion of results in the first three weeks of these foals compared with the following weeks. The growth and development of foals was directly related to genetic potential and other factors such as nutrition and exercise (Hunka et al., 2014). Thus, this smaller dispersion can be explained by the greater dependence on the diet of mares, as milk is the main source of nutrients; therefore, there is a lesser need for foals to get their own food; in addition, there is larger influence of the genetic factor in this phase, generating homogeneity among the animals. Considering that milk is the main source of food for foals in the first weeks, Faubladier et al. (2013) supplemented lactating mares with lactic fermentation products and sprouted cereal seeds. They observed great weight of foals at $19,26,40,54$, and 60 days old that may have occurred due to changes in the production and composition of the milk or changes in the maternal microbial ecosystem.

In the present study, as the supplementation was given directly to foals, the Faubladier et al. (2013) hypothesis is not applicable. Probably, the production and composition of the milk was similar and the colonization of the large intestine of the foals was performed passively through the microbiota of the respective mares (Earing et al., 2012; Faubladier et al., 2014) that did not receive any prebiotic FOS.

According to the results of the morphometric measurements, the value of withers height at birth $(86 \mathrm{~cm})$ was the same observed in Mangalarga Marchador foals by Almeida et al. (2000); however, Cabral et al. (2004), Santos et al. (2005), and Manso Filho et al. (2014) observed, in Mangalarga Marchador foals, mean withers height at birth of $89,92.9$, and $93.7 \mathrm{~cm}$, respectively, higher values than the ones presented in this study. Cabral et al. (2004) evaluated the growth of Mangalarga Marchador foals and recorded that the mean withers height at birth was 93.4 and $92.9 \mathrm{~cm}$ for males and females, respectively, corresponding to the 61.6 and $63.2 \%$ of the withers height expected at mature age. These values were higher than those observed in this study for the mare withers height (59.6\%). It should be emphasized that in the Cabral et al. (2004) study, a larger number of foals was evaluated in different farms, which may explain the difference in the percentual values.

Foals have high growth rates for the withers height during the first year of life and this is even more pronounced in the first months of life (Santos et al., 1992). The definite registration for Mangalarga Marchador horses requires that the withers height be at least 1.47 and $1.40 \mathrm{~cm}$, for males 
and females, respectively (ABCCMM, 2016), and 90\% of this height should appear by the time the foal is one year old (Reed and Dunn, 1977).

The mean values obtained for the croup height corresponded to 53 and $73.4 \%$ of the mare croup height, at birth and at 75 days of age, respectively. Cabral et al. (2004) observed values higher than those in the present study of 63.2 and $77.6 \%$ in relation to mare croup height, at birth and at three months old, respectively. The growth rate for both withers height and croup height is high according to Hintz et al. (1976), who explained that the larger growth is due to the rapid bone development during the first months of life.

Croup height is correlated with withers height, with mean values of croup height larger than $2-3 \mathrm{~cm}$ in this study, corroborating the results observed by Thompson (1995). The Mangalarga Marchador breed standard describes, for registration purposes, that height at the withers and at the croup are equal for males and for females it is acceptable up two centimeters in the height at the withers (ABCCMM, 2016). For the good body proportion of the breed, the croup must be long, muscular, proportional, with sacral tuberosity slightly protruding and gently inclined. The foals are born with the croup higher than the withers (Table 2), but the height at the withers presents greater growth, with higher values to the mature age (Cabral et al., 2004).

In Mangalarga Marchador morphology evaluations, the mid-back height and the thoracic circumference are important parameters, since they are indicative of the thoracic depth and characterize the cardiorespiratory capacity of the horse (Cabral et al., 2004). Cabral et al. (2004) observed a mean value for mid-back height of $29.5 \mathrm{~cm}$ at birth, which exceeded the mean value of $26 \mathrm{~cm}$ in the present study. In addition, a well-placed gravity center is desirable as it emphasizes the fitness of the Mangalarga Marchador breed, which is a model horse for saddle and carrying out daily activities. An ideal gravity center is when the mid-back height is equal, or close, to half the withers height.

Considering the mid-back height shorter than the substernal height, the horse is defined as "far from the ground", characterizing long limbs that are favorable for speed; however, when the mid-back height is larger than the substernal height, the horse is defined as "close to the ground", characterizing short limbs that are unfavorable for agility and more favorable for pulling (Ribeiro, 1988). Therefore, the mid-back height associated to the substernal height is an indicative of the dexterity and speed potential of horses. The average mid-back height and substernal height were 34 and $64.4 \mathrm{~cm}$ respectively, during the experimental period, defining the foals as "far from the ground".

Body length is one of the measures that has the highest rate of growth from birth to mature age. Cabral et al. (2004) observed a growth rate of $42.6 \%$ in Mangalarga Marchador foals from birth to three months old, similar to that observed in the present study, of $39.4 \%$ from birth to 75 days of age, while Reed and Dunn (1977) observed a growth rate of $46.3 \%$ from birth to 12 months old in Arabian foals. In Thoroughbred foals, Thompson (1995) observed a $60.6 \%$ growth for body length from two weeks to about one year old.

The literature data showed that the increase of body length varies according to specific breed and the present results clarify that the use of prebiotic in Mangalarga Marchador breed did not affect this variable. The body length of Mangalarga Marchador foals observed by Cabral et al. (2004) reached values of 44.4 and $63.4 \%$ of the body length of mares at birth and at three months old, respectively, similar to that observed in this study, of 42.2 and $58.9 \%$ of the body length of the mares from birth to 75 days of age, respectively.

Currently, the thoracic circumference measurement in foals is useful to estimate the body mass of the animal. However, there is a wide variation of this parameter, since it depends on the breed size and, consequently, the weight that they can reach at mature age. In this work, the thoracic circumference increased $27.5 \mathrm{~cm}$ from birth to 75 days old, which was close to the value observed by Cabral (2004) for Mangalarga Marchador foals, an increase of $32 \mathrm{~cm}$ in the thoracic circumference from birth to three months old. In Quarter horse foals, Hunka et al. (2014) reported thoracic circumference values of 78.7, 97.4, 106.9, and $115.4 \mathrm{~cm}$, at birth and at the first, second, and third months of life, respectively. The growth corresponds to a $46.6 \%$ increase from birth to three months, higher than that observed in the present study, of $38.8 \%$ from birth to 75 days of age.

Values of limb circumference are important to evidence the ability of movements and to support body weight of foals, mainly of the animals used for marching competitions. Values of forearm circumference of 20 and $26 \mathrm{~cm}$ in Mangalarga Marchador foals at birth and at three months old, respectively, were observed by Cabral et al. (2004), corresponding to an average increase of $6 \mathrm{~cm}$, similar to that observed in the foals of present study $(4.6 \mathrm{~cm})$. The same authors observed values of knee circumference of 21.2 and $24.9 \mathrm{~cm}$ in Mangalarga Marchador foals at birth and at three months old, respectively. These values corresponded to $17.4 \%$ growth, which was $5.4 \%$ higher than in the present 
study. Cabral et al. (2004) also recorded shin circumferences of 11.7 and $14.4 \mathrm{~cm}$ in Mangalarga Marchador foals at birth and at three months old, respectively, which correspond to an increase of 23.1\%. Manso Filho et al. (2014) observed 11.3 and $14.1 \mathrm{~cm}$ of shin circumference of Mangalarga Marchador foals at birth and at three months old, which corresponds to an increase of $24.8 \%$, while the present study reported an increase of $12.3 \%$.

Respondek et al. (2011) did not observe differences between obese horses supplemented with FOS and the control group for the morphometric variables of withers height, body length, and thoracic circumference, which is in agreement with the results observed in this study. A similar study was performed with prebiotic supplementation in neonatal dairy calves, evaluating their development from birth up to eight weeks old (Heinrichs et al., 2009) and no significant differences were observed in body weight, thoracic circumference, withers height, and croup height. The authors stated that, because the health of the animals was considered excellent, it was not possible to observe any improvement that could be attributed to the prebiotic as expected, given the potential of the supplement. In a study by Berg et al. (2005), conducted with mature horses, when FOS was added to the diet, 8.0 and $24 \mathrm{~g}$, the amount of potentially harmful bacteria decreased and the number of Escherichia coli colonies decreased, even though the Lactobacillus count did not change. This may have occurred in the present study, although the microorganisms were not counted, since no health problems were observed in the foals during the experimental period.

The evaluation of the morphological measures is of extreme importance for horse production, especially when it comes to growing foals, since, based on these measures, it is possible to follow the standard development using regression equations to estimate de growth, avoiding sub or super growth and compensatory gains. Moreover, these parameters can help in the selection of these young animals (Pinto et al., 2005; Godoi et al., 2013) as several factors can affect the growth of foals mainly at this age, including the month of birth, availability of pasture, sex, creep feeding, and use of various additives, among others.

The use of more objective evaluations is necessary to affirm the effect of the prebiotic FOS on the foal health, which unfortunately could not be done in this study. In addition, as this is a very specific and important age, more studies during this phase are necessary, especially those related to equine development, as well as the effects of prebiotic supplementation and colonization of the intestinal microbiota.

\section{Conclusions}

The prebiotic fructooligosaccharides do not promote significant differences in the development of suckling foals from birth to 75 days of age. Foals supplemented or not with prebiotics follow the normal growth pattern of the Mangalarga Marchador breed for the evaluated age and the regression equations of the variables can be used to predict the morphometric measures of Mangalarga Marchador suckling foals. Although they do not improve foal development, fructooligosaccharides have potential to affect the gastrointestinal well-being, improve feed conversion, and suppress pathogenic bacterial growth.

\section{Acknowledgments}

The article is part of the dissertation of the first author presented to the Graduate Program in Animal Science of the Universidade Federal Rural do Rio de Janeiro (UFRRJ). The authors thank the Institute of Animal Science of UFRRJ, for the support for this research; the Coordenação de Aperfeiçoamento de Pessoal de Nível Superior (CAPES), for the Master's fellowship grant to the first author; the Fundação de Amparo à Pesquisa do Estado do Rio de Janeiro (FAPERJ), for the expended resources; and Cabral's Haras, for providing the Mangalarga Marchador foals and infrastructure support for this study.

\section{References}

Almeida, F. Q.; Brito, C. O.; Santos, E. M.; Almeida, M. I. V.; Lopes, B.; Corassa, A. and Soares Neto, J. 2000. Crescimento de potros da raça Mangalarga Marchador. p.642. In: Anais da $37^{\mathrm{a}}$ Reunião Anual da Sociedade Brasileira de Zootecnia. Sociedade Brasileira de Zootecnia, Viçosa, MG.

ABCCMM - Associação Brasileira dos Criadores do Cavalo Mangalarga Marchador. 2016. Padrão da raça. Belo Horizonte. Available at: <http://www.abccmm.org.br/uploads/542--Padrao da_Raca.pdf.pdf $>$ Accessed on: June 18, 2016.

Berg, E. L.; Fu, C. J.; Porter, J. H. and Kerley, M. S. 2005 Fructooligosaccharides supplementation in the yearling horse: Effects on fecal $\mathrm{pH}$, microbial content, and volatile fatty acid concentrations. Journal of Animal Science 83:1549-1553.

Cabral, G. C.; Almeida, F. Q.; Quirino, C. R.; Pinto, L. F. B.; Santos, E. M. and Corassa, A. 2004. Avaliação morfométrica de eqüinos da raça Mangalarga Marchador: medidas lineares. Revista Brasileira de Zootecnia 33:989-1000.

Earing, J. E.; Durig, A. C.; Gellin, G. L.; Lawrence, L. W. and Flythe, M. D. 2012. Bacterial colonization of the equine gut: comparison of mare and foal pairs by PCR-DGGE. Advances in Microbiology 2:79-86.

Faubladier, C.; Julliand, V.; Danel, J. and Philippeau, C. 2013. Bacterial carbohydrate-degrading capacity in foal faeces: changes from birth to pre-weaning and the impact of maternal supplementation with fermented feed products. British Journal of Nutrition 1:1-13. 
Faubladier, C.; Sadet-Bourgeteau, S.; Philippeau, C.; Jacotot, E. and Julliand, V. 2014. Molecular monitoring of the bacterial community structure in foal feces pre- and post-weaning. Anaerobes 25:61-66.

Gibson, G. R. and Roberfroid, M. B. 1995. Dietary modulation of the human colonic microbiota: introducing the concept of prebiotics. Journal of Nutrition 125:1401-1412.

Gibson, G. R. and Wang, X. 1994. Regulatory effects of bifidobacteria on the growth of other colonic bacteria. Journal of Applied Bacteriology 77:412-420.

Godoi, F. N.; Bergmann, J. A. G.; Almeida, F. Q.; Santos, D. C. C.; Miranda, A. L. S.; Vasconcelos, F. O.; Oliveira, J. E. G.; Kaipper, R. R. and Andrade, A. M. 2013. Morfologia de potros da raça Brasileiro de Hipismo. Ciência Rural 43:736-742.

Gürbüz, E.; İnal, F.; Ata, S. U.; Çitil, O. B.; Kav, K. and Küçükkaya, F. 2010. Effects of supplemental fructo-oligosaccharide and mannanoligosaccharide on nutrient digestibilities, volatile fatty acid concentrations, and immune function in horses. Turkish Journal of Veterinary and Animal Science 34:39-44.

Heinrichs, A. J.; Jones, C. M.; Elizondo-Salazar, J. A. and Terrill, S. J. 2009. Effects of a prebiotic supplement on health of neonatal dairy calves. Livestock Science 125:149-154.

Hintz, H. F.; Schryver, H. F. and Lowe, J. E. 1976. Delayed growth response and limb conformation in young horses [Contracted tendons, nutritional deficiencies]. p.94-96. In: Proceedings of 38th Cornell Nutrition Conference for Feed Manufacturers. Cornell University, Ithaca.

Hunka, M. M.; Costa Cordeiro, H. E. C.; Bernardo, R. B.; Silva, E. R. R.; Ferreira, L. M. C. and Manso Filho, H. C. 2014. Development and body composition of Quarter Horse foals during nursing. Open Journal of Veterinary Medicine 4:276-280.

Magdesian, K. G. 2005. Neonatal foal diarrhea. Veterinary Clinics of North America: Equine Practice 21:295-312.

Manso Filho, H. C.; Wanderley, E. K.; Rosário, B. M.; Gir, J. M. and Manso, H. E. C. C. 2014. Pattern of development in foals from four different breeds between birth and weaning. Open Journal of Veterinary Medicine 4:72-77.

NRC - National Research Council. 2007. Nutrients requirements of horses.6th ed. National Academy of Science, Washington, DC.

Pinto, L. F. B.; Almeida, F. Q.; Quirino, C. R.; Azevedo, P. C. N.; Cabral, G. C.; Santos, E. M. and Corassa, A. 2008. Evaluation of the sexual dimorphism in Mangalarga Marchador horses using discriminant analysis. Livestock Science 119:161-166.
Pinto, L. F. B.; Almeida, F. Q.; Quirino, C. R; Azevedo, P. C. N.; Cabral, G. C. and Corassa, A. 2005. Análise multivariada das medidas morfométricas de potros da raça Mangalarga Marchador: análise de componentes principais. Revista Brasileira de Zootecnia 34:589-599.

Reed, K. R. and Dunn, N. K. 1977. Growth and development of the Arabian horse. p.76-98. In: Proceedings of Equine Nutrition and Physiology Symposium. University of Missouri, St. Louis, MO.

Respondek, F.; Myers, K.; Smith, F. T. L.; Wagner, A. and Geor, R. J. 2011. Dietary supplementation with short-chain fructooligosaccharides improves insulin sensitivity in obese horses. Journal of Animal Science 89:77-83.

Ribeiro, D. B. 1988. O cavalo de raças, qualidade e defeitos. Editora Globo Rural, Rio de Janeiro.

Santos, S. A.; Carvalho, R. T. L.; Couto, H. T. Z. and Mazza, M. C. M. 1992. Influência de alguns fatores ambientais sobre características de crescimento de cavalos Brasileiro de Hipismo até um ano de idade. Pesquisa Agropecuária Brasileira 27:171-179.

Santos, E. M.; Almeida, F. Q.; Vieira, A. A.; Pinto, L. F. B.; Corassa, A.; Pimentel, R. R. M.; Silva, V. P. and Galzerano, L. 2005. Lactação em éguas da raça Mangalarga Marchador: produção e composição do leite e ganho de peso dos potros lactentes. Revista Brasileira de Zootecnia 34:627-634.

Thompson, K. N. 1995. Skeletal growth rates of weanling and yearling thoroughbred horses. Journal of Animal Science $73: 2513-2517$

Thompson, C. L.; Wang, B. and Holmes, A. J. 2008. The immediate environment during postnatal development has long-term impact on gut community structure in pigs. The ISME Journal 2:739-748.

Van Leeuwen, P. and Verdonk, J. M. A. J. 2004. The gastro-intestinal degradation of inulin preparations and their effects on production performance and gut microflora in calves. Animal Sciences Group Wagingen UR, Lelystad, Netherlands, Project nr 825.20552.02, Report No: 04/100287: 1-31.

Yáñez-Ruiz, D. R.; Macías, B.; Pinloche, E. and Newbold, C. J. 2010. The persistence of bacterial and methanogenic archaeal communities residing in the rumen of young lambs. FEMS Microbiology Ecology 72:272-278.

Waldroup, A. L.; Skinner, J. T.; Hierholzer, R. E. and Waldroup, P. W. 1993. Anevaluation of fructooligosaccharide in diets for broiler chickens and effects onsalmonellae contamination of carcasses. Poultry Science 72:643-650. 